\title{
Bleaching effect on regeneration and resource translocation in the coral Oculina patagonica
}

\author{
M. Fine, U. Oren, Y. Loya* \\ Department of Zoology, The George S. Wise Faculty of Life Sciences, Tel Aviv University, Tel Aviv 69978, Israel
}

\begin{abstract}
Bleaching of corals is the result of the loss of their symbiotic algae (zooxanthellae) and/or their pigments. The supply of photoassimilates provided by the zooxanthellae to the corals declines during bleaching and reduces their ability to activate energy-costly processes. In the present study we compared regeneration capabilities of unbleached Oculina patagonica colonies (an encrusting Mediterranean stony coral) with those of bleached and partly bleached colonies. Using the ${ }^{14} \mathrm{C}$ point-labelling technique on coral tissue, we examined possible intra-colonial translocation of photosynthetic products from the site of tissue labelling to recuperating lesions in partly bleached versus unbleached intact colonies. The percentage recovery of $2 \mathrm{~cm}^{2}$ lesions inflicted on unbleached $O$. patagonica colonies was significantly higher than the percentage recovery of similar lesions within the bleached area of the partly bleached colonies. Totally bleached colonies showed no regeneration of lesions. Lesion regeneration in unbleached O. patagonica resulted in oriented intra-colonial translocation of ${ }^{14} \mathrm{C}$ products towards recuperating lesions located up to $4-5 \mathrm{~cm}$ away. In partly bleached colonies (40 to $80 \%$ ), such translocation did not occur, probably explaining the reduced recovery rates of lesions in these colonies. Our findings suggest a bleaching threshold of ca. $30 \%$ within O. patagonica colonies that determines the levels of colony integration and intra-colonial translocation of resources to regions of maximal demand.
\end{abstract}

KEY WORDS: Coral bleaching $\cdot$ Lesion recovery $\cdot{ }^{14} \mathrm{C}$-labelling $\cdot$ Colony integration $\cdot$ Resource translocation · Oculina patagonica

\section{INTRODUCTION}

Coral bleaching disrupts the symbiotic association between coral hosts and their symbiotic photosynthetic algal endosymbionts. Recent reports of world-wide coral bleaching events leading to unprecedented and devastating coral mortality have caused alarm among scientists and resource managers (Hoegh-Guldberg 1999, Wilkinson 1999, 2000). Coral bleaching is often linked to global climate change, especially elevated seawater temperature (Glynn 1991, 1993, Brown 1997, Hoegh-Guldberg 1999) and high solar irradiance (Jokiel 1980, Lesser et al. 1990, Gleason \& Wellington 1993, Glynn 1993). Bleaching of Oculina patagonica, an

*Corresponding author. E-mail: yosiloya@post.tau.ac.il encrusting Mediterranean stony coral common along the Mediterranean coast of Israel (Fine et al. 2001), was first recorded in summer 1993. This bleaching was explained by a bacterial infection, to which elevated temperature was a contributing factor (Kushmaro et al. 1996, 1998). Bleaching events have since occurred annually, starting in late May, concomitant with the rise in seawater temperature (Kushmaro et al. 1998). In contrast to reports from other regions of mass mortality following bleaching events, over $90 \%$ of the bleached $O$. patagonica colonies fully recovered the following winter (Kushmaro et al. 1998) through division of the remaining symbiotic zooxanthellae and/or recruitment of zooxanthellae from the ambient water.

During bleaching, hermatypic corals may sometimes suffer damage from a multitude of other agents (apart from the loss of their main energy source), such as 
storms (Scoffin 1993), sedimentation (Loya 1976a, Rogers 1990), temperature fluctuations (Jokiel \& Coles 1990), emersion at low tide (Loya 1972, 1976b), diseases (Gladfelter 1982, Peters 1984, Brown 1997), competitive interactions (Chornesky 1989), anthropogenic stresses (Brown \& Howard 1985) and predation (Cameron et al. 1991). Colonies of Oculina patagonica are often preyed upon by the polychaete Hermodice carunculata. This nocturnal predatory worm uses itsjaws to scrape the coral tissue off its skeleton, causing round tissue lesions (Fig. 1) which are also observed during bleaching events. Witman (1988) reported permanent damage to milleporid hydrocorals after predation by $H$. carunculata that resulted in lower colony growth. Similar observations were made by Vreeland \& Lasker (1989) in the Caribbean, where H. carunculata preyed upon gorgonians.

Lesion regeneration in corals was formerly regarded as a localized energy process that does not require extensive colony integration (Bak \& Steward-van Es 1980, Meesters \& Bak 1993, Meesters et al. 1997). However, in recent years, we have found that lesions may activate an oriented intra-colonial transport of photoassimilates to the injured tissue (Oren et al. 1997, 1998), and that resources required for lesion recovery are supplied not only by the polyps directly bordering the injured area, but also by those located further away, up to $10 \mathrm{~cm}$ from the injured area (Oren et al. 1997). Recently, Oren et al. (2001) found that the extent of this resource translocation is regulated by the size and shape of the lesion.

Corals have a limited set of resources, such as energy and interstitial cells, which have to be shared amongst a variety of life functions including sexual and asexual reproduction, growth, maintenance and repair (Kozlowski \& Wiegert 1986, Harrison \& Wallace 1990,

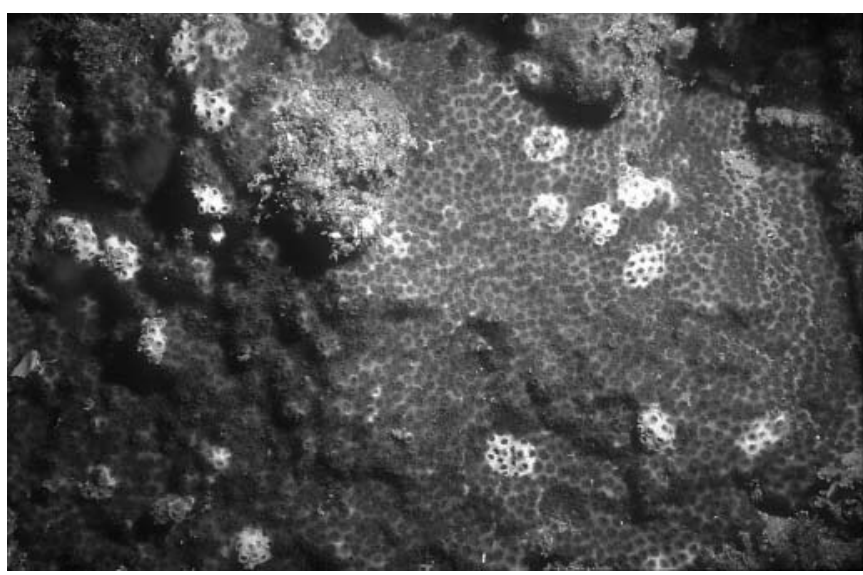

Fig. 1. Oculina patagonica. Round tissue lesions on surface following predation by polychaete Hermodice carunculata (photograph is $38 \%$ actual size)
Kramarsky-Winter \& Loya 2000). Consequently, intracolonial energy and resource integration is regarded as a basic life-preserving ability and one of the most important advantages of clonal and colonial organisms. However, despite extensive knowledge regarding the energetic importance of symbiotic zooxanthellae for colony maintenance and survival, and the accepted importance of colony integration during stress, intra-colonial integration and resource translocation in bleached corals has not yet been investigated.

In the present study we inflicted artificial lesions, similar to those caused by Hermodice carunculata, in order: (1) to compare the regeneration capabilities of healthy unbleached Oculina patagonica colonies with those of bleached and partly bleached corals; and (2) to examine possible intra-colonial translocation of photosynthetic products to regenerating lesions in unbleached versus partly bleached colonies.

\section{MATERIALS AND METHODS}

The entire study was performed in the field at SdotYam (Mediterranean coast of Israel: $32^{\circ} 29.77^{\prime} \mathrm{N}$, $34^{\circ} 53.23^{\prime} \mathrm{E}$ ) along the vermetid reefs in a depth range of 3 to $6 \mathrm{~m}$.

Lesion recovery rates in unbleached versus partly and totally bleached colonies. During June to August 2000 we examined the recovery rates (\%) of round tissue lesions (projected lesion size $=2 \mathrm{~cm}^{2}$ ), artificially inflicted on the surface of 34 similar sized colonies of Oculina patagonica (ca. 12 to $14 \mathrm{~cm}$ in diameter). Within this group 13 colonies were unbleached, 11 were partly bleached, and 10 were totally bleached. Since bleached and unbleached sections of the colony can be distinguished by a distinct border, colonies with 30 to $80 \%$ bleached surface area were marked as partly bleached. The lesions were created using an air-pick jet, which removes local tissue, causing no damage to the skeleton beneath. Each unbleached and totally bleached colony was inflicted with 1 lesion in its center, while each partly bleached colony was inflicted with 1 lesion in the center of the bleached section. All examined colonies were photographed using a Nikonos-V camera with a $35 \mathrm{~mm}$ lens on a 1:1 extension tube, enabling accurate measurement of lesion size, and a $28 \mathrm{~mm}$ close-up attachment for bleaching percentage measurements (\% of bleached surface area). An image-analyzer (Olympus, CUE-3) was used to analyze the color slides. Forty-five days after injury, the lesions were rephotographed and analyzed by the image-analyzer, enabling accurate calculation of the percentage lesion healing. After transforming percentage data by arcsine $\sqrt{ } \mathrm{p}$, a 1-way ANOVA was used to test the difference in lesion recovery between healthy and partly bleached colonies. 
Radioactive labelling procedure. To study the possible intra-colonial translocation of photosynthetic products within colonies of Oculina patagonica, we used ${ }^{14} \mathrm{C}$-labelling cylinders (see Oren et al. 1997) that enabled coral tissue-labelling on a limited colony portion of $5 \mathrm{~cm}^{2}$. A firm seal with the coral tissue was achieved by self-adhesive foam glued to the opening of each cylinder. Final attachment of the cylinders to the coral surface was accomplished by wires anchored to the substrate near the colony. A $0.5 \mathrm{~mm}$ hole covered with rubber enabled injection of the radioactive carbon into each cylinder (final concentration $0.01 \mu \mathrm{Ci} \mathrm{ml}^{-1}$ ). ${ }^{14} \mathrm{C}$ labelling of all experimental colonies was initiated at 09:00 $\mathrm{h}$ for a total period of $24 \mathrm{~h}$, after which the cylinders were removed. Coral fragments of $1 \mathrm{~cm}^{2}$ (tissue + skeleton) were sampled $48 \mathrm{~h}$ after removal of the labelling cylinders. Each fragment was placed individually in a plastic vial and transferred to the laboratory. The seawater was drained from each vial and $8 \mathrm{ml}$ of hydrogen peroxide ( $30 \%$ ) were added to digest the tissues. After complete tissue digestion $(24 \mathrm{~h})$, the remaining skeletons were removed and 2 replicates of $0.5 \mathrm{ml}$ each from each vial were transferred to separate vials, each containing $5 \mathrm{ml}$ of Biodegradable Counting Scintillation cocktail (BCS, Amersham). The activity of ${ }^{14} \mathrm{C}$ in the tissues was determined by liquid scintillation counter (Packard, Tri-Carb 1500).

All colonies in the experiments were photographed using a Nikonos-V camera with $28 \mathrm{~mm}$ close-up attachment, enabling measurement of bleaching percentage ( $\%$ of bleached surface area) by an imageanalyzer (Olympus, CUE-3).

Intra-colonial translocation in bleached colonies. To examine the possible intra-colonial translocation of photosynthetic products from unbleached colony sections to bleached colony sections, we conducted ${ }^{14} \mathrm{C}$-labelling in 4 partly bleached colonies $(12$ to $15 \mathrm{~cm}$ in diameter). In each of these colonies, the labelling cylinder was attached to the unbleached colony section at a distance of 4 to $5 \mathrm{~cm}$ from the border line of the bleached section (Fig. 2A). Five coral samples (tissue and skeleton) were taken from each labelled colony $48 \mathrm{~h}$ after removal of the labelling cylinder (sampling sites in Fig. 2A). A 1-way ANOVA with repeated measures, followed by an LSD test were used to compare ${ }^{14} \mathrm{C}$ activity in the sampling site bordering the bleached section with that opposite the bleached section.

${ }^{14} \mathrm{C}$ translocation during regeneration in unbleached versus bleached colonies. To examine the possible translocation of photosynthetic products in injured colonies of Oculina patagonica, we conducted ${ }^{14} \mathrm{C}$-labelling on 13 additional colonies (unbleached $\mathrm{n}=$ 4 , partly bleached $\mathrm{n}=9)$. One tissue lesion $\left(2 \mathrm{~cm}^{2}\right)$ was inflicted on the surface of each of these colonies immediately after attachment of the labelling cylinders, as
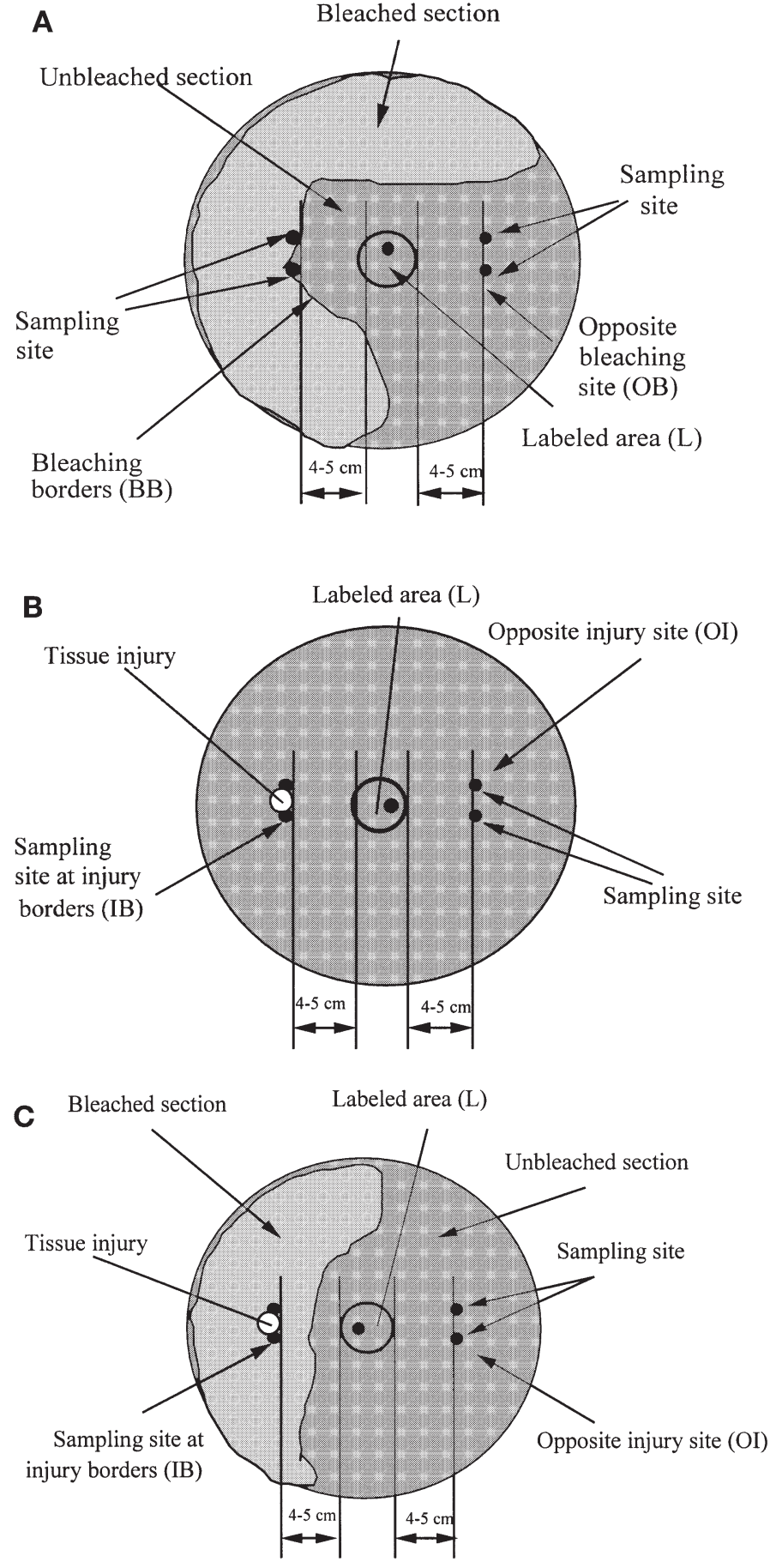

Fig. 2. Oculina patagonica. Schematic diagram of ${ }^{14} \mathrm{C}$ labelling and sampling sites in (A) partly bleached colonies ( $\mathrm{n}=$ $4)$, (B) experimentally injured healthy colonies $(n=4)$, and (C) experimentally injured, partly bleached colonies $(n=9)$. L: labelled area; BB: border line of bleached area located 4 to $5 \mathrm{~cm}$ away from labelled area; OB: sites opposite bleaching border, also 4 to $5 \mathrm{~cm}$ from labelled area; IB: injury border located 4 to $5 \mathrm{~cm}$ away from labelled area; OI: sites opposite injury border, 4 to $5 \mathrm{~cm}$ from labelled area; (-) sites from which tissue fragments were taken for measurement of ${ }^{14} \mathrm{C}$ activity 
Table 1. Oculina patagonica. Percentage lesion recovery over $45 \mathrm{~d}$ of $2 \mathrm{~cm}^{2}$ lesions inflicted on the surface of unbleached ( $\mathrm{n}=13)$, partly bleached ( 30 to $80 \%)(\mathrm{n}=11)$ and totally bleached $(n=10)$ colonies

\begin{tabular}{|lccc|}
\hline Colony no. & Unbleached & $\begin{array}{c}\text { Partly } \\
\text { bleached }\end{array}$ & $\begin{array}{c}\text { Totally } \\
\text { bleached }\end{array}$ \\
\hline 1 & 91 & 4 & 0 \\
2 & 100 & 0 & 0 \\
3 & 85 & 0 & 0 \\
4 & 64 & 49 & 0 \\
5 & 75 & 85 & 0 \\
6 & 100 & 0 & 0 \\
7 & 100 & 0 & 0 \\
8 & 100 & 13 & 0 \\
9 & 100 & 13 & 0 \\
10 & 100 & 38 & 0 \\
11 & 100 & 39 & \\
12 & 81 & & \\
13 & 100 & & \\
Mean \pm SD & $92.0 \pm 12.0 \%$ & $21.9 \pm 27.7 \%$ & \\
\multicolumn{4}{l}{} \\
\hline
\end{tabular}

follows: in the 4 unbleached colonies the lesions were inflicted at a distance of 4 to $5 \mathrm{~cm}$ from the ${ }^{14} \mathrm{C}$ labelling site (Fig. 2B), while in the 9 partly bleached colonies the lesions were inflicted in the bleached section, at a similar distance of 4 to $5 \mathrm{~cm}$ from the labelling site (Fig. 2C). Five coral samples were taken from each labelled colony $48 \mathrm{~h}$ after removal of the labelling cylinders (sampling sites in Fig. 2B,C). A 1-way ANOVA with repeated measures, followed by an LSD test were used to compare ${ }^{14} \mathrm{C}$ activity in the sampling site bordering the lesion with that opposite the lesion in each of the healthy, partly bleached and totally bleached colonies.

Table 2. Oculina patagonica. Average ${ }^{14} \mathrm{C}$ activity (counts $\mathrm{min}^{-1} \mathrm{~cm}^{-2} \pm \mathrm{SD}$ ) in coral tissues in partly bleached colonies $(n=4)$. Percentage bleaching of each colony is presented in left column. L: coral tissue taken from labelled site; BB: coral tissue from border of bleached section, located 4 to $5 \mathrm{~cm}$ from labelled area; OB: coral tissue from sites opposite the bleached area, 4 to $5 \mathrm{~cm}$ from labelled site. Each tissue sample was divided into 2 replicates for measurement of ${ }^{14} \mathrm{C}$ activity. Average background activity of tissues $=29 \pm 6$ counts $\mathrm{min}^{-1} \mathrm{~cm}^{-2}$ (intact control colonies, $\mathrm{n}=6$ ). Two tissue samples were taken from the $\mathrm{BB}$ and $\mathrm{OB}$ areas and divided into 2 replicates each. Data for $\mathrm{L}$ represent range of ${ }^{14} \mathrm{C}$ activity. Data for $\mathrm{BB}$ and $\mathrm{OB}$ are for samples with 2 replicates each

\begin{tabular}{|lcccc|}
\hline $\begin{array}{l}\text { Colony } \\
\text { no. }\end{array}$ & $\begin{array}{c}\% \\
\text { bleached }\end{array}$ & L & Sampling site \\
\hline 1 & 55 & $10945-11625$ & $24.0 \pm 4.7$ & OB \\
\hline 2 & 65 & $8231-9408$ & $33.0 \pm 14.6$ & $25.2 \pm 4.6$ \\
3 & 70 & $12204-14782$ & $26.5 \pm 4.0$ & $21.5 \pm 2.0$ \\
4 & 80 & $5768-6320$ & $31.5 \pm 3.7$ & $24.0 \pm 2.6$ \\
\hline
\end{tabular}

\section{RESULTS}

\section{Lesion recovery rates in unbleached versus partly and totally bleached colonies}

Percentage recovery of the $2 \mathrm{~cm}^{2}$ lesions inflicted on the unbleached Oculina patagonica colonies $(\mathrm{n}=13$, Table 1) was significantly higher than percentage recovery of the lesions inflicted on the partly bleached colonies (ANOVA after transforming percentage data by arcsine $\sqrt{ } \mathrm{p}, \mathrm{p}<0.001$, df $=1, F=68.4, \mathrm{n}=11$ ). Only 1 lesion in the partly bleached colonies attained a recovery of $85 \%$, whereas most lesions in the unbleached colonies healed completely over the $45 \mathrm{~d}$ period (Table 1).

The bleached colonies $(n=10)$ showed no recovery from the inflicted lesions even after $65 \mathrm{~d}$ (Table 1).

\section{Intra-colonial translocation in partly bleached colonies}

Forty-eight hours after ${ }^{14} \mathrm{C}$-labelling treatments, the $5 \mathrm{~cm}^{2}$ labelled areas in all experimental colonies (L, Tables $2 \& 3$ ) displayed high ${ }^{14} \mathrm{C}$ activity compared to background ${ }^{14} \mathrm{C}$ activity (i.e. ${ }^{14} \mathrm{C}$ activity in healthy randomly sampled intact Oculina patagonica colonies $=29 \pm 6$ counts $\mathrm{min}^{-1} \mathrm{~cm}^{-2}, \mathrm{n}=6$ ). Coral tissues taken from the borders of the bleached colony section and from the site opposite the bleached section (Sites BB and OB: Fig. 2, Table 2) located 4 to $5 \mathrm{~cm}$ away from the labelling area exhibited ${ }^{14} \mathrm{C}$ activity that did not differ significantly from that of the intact control tissues (1-way ANOVA with repeated measures, LSD p > 0.05, $\mathrm{df}=1, F=0.5)$.

\section{${ }^{14} \mathrm{C}$ translocation during regeneration in healthy versus bleached colonies}

The 1-way ANOVA with repeated measures showed no significant difference between sampling Site OI (from unbleached colonies and partly bleached colonies with $>40 \%$ bleaching) and the background ${ }^{14} \mathrm{C}$ activity $(\mathrm{p}>0.05, \mathrm{df}=2, F=61.82)$. These results indicate that partly bleached colonies (percentage bleaching $>40 \%$ ) of Oculina patagonica do not transfer photosynthetic products from unbleached colony sections to lesions in the bleached sections. In contrast, a significant difference in ${ }^{14} \mathrm{C}$ activity was found between sampling Site IB (from unbleached colonies and partly bleached colonies with $<40 \%$ bleaching) and the background ${ }^{14} \mathrm{C}$ activity (1-way ANOVA with repeated measures, $\mathrm{p}<0.001$, $\mathrm{df}=2, F=42.76)$. The LSD test revealed that coral tissues taken from the 
borders of the lesions in the intact healthy colonies (Site IB; Colonies 1 to 4 in Table 3; Sampling site in Fig. 2C), exhibited significantly higher ${ }^{14} \mathrm{C}$ activity than background levels (LSD $p<0.001$ ). These results demonstrate the ability of unbleached $O$. patagonica colonies to translocate photosynthetic products to recuperating injuries. Tissue samples taken from the borders of the lesions inflicted on the partly bleached colonies (Site IB; Colonies 9 to 13 in Table 3; Sampling sites in Fig. 2C), exhibited ${ }^{14} \mathrm{C}$ activity that did not differ significantly from the background levels (LSD $\mathrm{p}>0.05$ ). Insignificant ${ }^{14} \mathrm{C}$ activity (compared to background levels) was also recorded for tissue samples taken from opposite the injury (Site OI; Table 3, p > 0.05; Sampling sites OI in Fig. 2C). Among the 9 partly bleached colonies, only 4 colonies (Colonies 5 to 8 , exhibiting 15 to $35 \%$ bleaching) demonstrated oriented translocation of ${ }^{14} \mathrm{C}$ products to lesions (Table 3).

\section{DISCUSSION}

In this study we have shown that (1) Lesion regeneration in unbleached healthy Oculina patagonica colonies is significantly higher than that in partially bleached colonies; totally bleached colonies showed no lesion recovery. (2) Lesion regeneration is coupled with resource translocation to the recovering lesion borders. (3) During bleaching, a low integration capacity of the colony results in lower resource translocation capabilities.

Although mortality may not be the eventual outcome (Hoegh-Guldberg 1999), bleached corals show reduced growth (Goreau \& Macfarlane 1990), reproduction (Szmant \& Gassman 1990, Ward 2000), calcification and repair capabilities (Glynn 1993, Meesters \& Bak 1993). As zooxanthellae are the principal engine of primary production in these organisms, the rate of photosynthetic productivity of reef-building corals and other symbiotic organisms drops dramatically (HoeghGuldberg 1999).

Lesion recovery in corals is an energy-costly process that is fundamental to coral survival (Oren et al. 2001). For most coral species the rapidity of this process is highly important, since fast lesion healing precludes settlement and subsequent overgrowth by competing organisms or total disruption of the physiological integration capacity of the colony (Loya 1976a, Wahle 1983, Brown \& Howard 1985, Jokiel \& Coles 1990, Cameron et al. 1991, Rogers 1993, Ward 1995). No lesion recovery of totally bleached Oculina patagonica colonies and significantly lower lesion recovery rates by partly bleached colonies compared with unbleached colonies (Table 1) indicate that an overall
Table 3. Oculina patagonica. Average ${ }^{14} \mathrm{C}$ activity (counts $\left.\mathrm{min}^{-1} \mathrm{~cm}^{-2} \pm \mathrm{SD}\right)$ in coral tissues in unbleached $(\mathrm{n}=4)$ and partly bleached colonies $(n=9)$. Percentage bleaching of each colony is presented in left column. L: coral tissue taken from labelled site; IB: coral tissue from injury border, located 4 to $5 \mathrm{~cm}$ from labelled site; OI: coral tissue from sites opposite injury, 4 to $5 \mathrm{~cm}$ from labelled site. Further details as in Table 1. Data for L represent range of ${ }^{14} \mathrm{C}$ activity. Data for IB and OI are for 2 samples with 2 replicates each

\begin{tabular}{|lcccc|}
\hline \multirow{2}{*}{$\begin{array}{l}\text { Colony } \\
\text { no. }\end{array}$} & $\begin{array}{c}\% \\
\text { bleached }\end{array}$ & $\mathrm{L}$ & Sampling site \\
& & & & IB \\
\hline 1 & 0 & $8615-11025$ & $201.2 \pm 43.6$ & $24.7 \pm 5.5$ \\
2 & 0 & $8670-8764$ & $170.2 \pm 2.0$ & $22.5 \pm 2.0$ \\
3 & 0 & $6429-6527$ & $132.5 \pm 6.6$ & $27.2 \pm 4.2$ \\
4 & 0 & $28780-30674$ & $453.0 \pm 13.0$ & $51.0 \pm 1.4$ \\
5 & 15 & $14019-14055$ & $443 \pm 18.0$ & $96.5 \pm 4.6$ \\
6 & 20 & $27856-27806$ & $263.7 \pm 42.3$ & $71.0 \pm 5.7$ \\
7 & 25 & $11024-11089$ & $329.5 \pm 62.0$ & $47.0 \pm 3.9$ \\
8 & 35 & $40757-43606$ & $308.5 \pm 13.9$ & $61.2 \pm 23.6$ \\
9 & 40 & $14925-15042$ & $73.2 \pm 7.5$ & $49.5 \pm 20.6$ \\
10 & 55 & $4662-4936$ & $30.2 \pm 5.0$ & $30.0 \pm 3.3$ \\
11 & 65 & $10785-10819$ & $21.5 \pm 0.5$ & $28.7 \pm 6.6$ \\
12 & 70 & $9724-10071$ & $24.0 \pm 3.8$ & $27.0 \pm 4.2$ \\
13 & 80 & $21346-22964$ & $21.5 \pm 6.1$ & $25.5 \pm 4.7$ \\
& & & & \\
\hline
\end{tabular}

low energetic state of colonies is caused by the loss of symbiotic algae. We assume that this resource deficiency is the factor also responsible for termination of gametogenesis in bleached $O$. patagonica colonies (Fine et al. 2001), as well as for the dramatic reduction in colony growth during the 5 mo (June to October) of the bleaching event (Fine unpubl. data). Previous studies have reported cessation of growth (Goreau \& Macfarlane 1990) and reproduction (Szmant \& Gassman 1990, Ward 2000, Fine et al. 2001) in bleached corals. In addition, Meesters \& Bak (1993) demonstrated the negative effect of bleaching on regeneration rates of the stony corals Montastrea annularis, Porites astreoides and Meandrina meandrites. They also found that mortality in bleached colonies of $M$. annularis and $P$. astreoides was higher than in intact colonies. Although those studies have already suggested that the effect of bleaching on recovery is related to the link between bleaching and energy-costly processes (i.e. growth, reproduction and regeneration), the present study shows that this linkage is caused by reduction of colony integration.

An important consequence of modularity is reflected in the colony's ability to continually re-allocate the priority of resource transport among its units in response to environmental changes and various stresses caused by biotic or abiotic factors. The intra-colonial transport of organic compounds within hermatypic corals is in fact a well-known phenomenon (Muscatine \& Porter 1977, Taylor 1977, Muscatine et al. 1981). Pearse \& Muscatine (1971) have already suggested that sym- 
biont photosynthates are translocated throughout the coral tissue to regions of maximal demand. Oren et al. $(1997,1998)$ showed an oriented intra-colonial transport of ${ }^{14} \mathrm{C}$-labelled materials to regenerating areas in the massive stony corals Favia favus, Platygyra lamellina and Porites sp. Both studies indicated the importance of intra-colonial resource translocation for achieving fast lesion recovery. The results obtained in the present study confirm that such oriented translocation also occurs in injured colonies of the Mediterranean coral Oculina patagonica (Table 3). Moreover, we have shown that a bleaching percentage above a threshold of ca. $40 \%$ terminates intra-colonial resource translocation in O. patagonica (Table 3). Of the 9 partly bleached colonies examined by ${ }^{14} \mathrm{C}$-labelling (Fig. 2C), only 4 demonstrated ${ }^{14} \mathrm{C}$ translocation to the site of injury (Colonies 5 to 8 ; Table 3 ). It should be noted that these particular colonies were 15 to $35 \%$ bleached, whereas the bleaching percentage of the other colonies ranged from 40 to $80 \%$ (Colonies 9 to 13; Table 3). This result may indicate the existence of a bleaching threshold, according to which the colony regulates its rate of resource allocation. The existence of colony thresholds that determine resource allocation and the onset of intra-colonial translocation of these resources reflects a basic life-preserving strategy and constitutes one of the most important advantages of clonal and colonial organisms. Based on the known importance of resource translocation for lesion regeneration, we suggest that the relatively low recovery rates characterizing partly bleached colonies compared with unbleached ones (Table 1) are due to a controlled 'blockage' of the unbleached colony section from the bleached section. Moreover, impaired movement of photosynthates and cells within the gastrovascular cavity cannot be ruled out. It is logical to assume that the breakdown of resource flow within bleached colonies is the key factor responsible for the negative effects of bleaching on various energy-costly processes in corals. At the same time, it is possible that such detachment between the intact sections of the colony and the bleached sections contributes to overall colony survival by preserving the resources within that section with greatest chances of recovery after the bleaching event.

Further examination of intra-colonial integration in tropical coral species that undergo bleaching will contribute additional vital knowledge regarding the ability of corals to survive bleaching events.

Acknowledgements. We thank the staff of the Sdot-Yam Marine Laboratory. We are grateful to N. Paz for her editorial assistance. This research was supported by the US-Israel Binational Science foundation (BSF) and the Raynor Chair for Environmental Conservation Research to Y.L.

\section{LITERATURE CITED}

Bak RPM, Steward-van Es Y (1980) Regeneration of superficial damage in the scleractinian corals Agaricia agaricites f. purpurea and Porites astreoides. Bull Mar Sci 30: 883-887

Brown BH (1997) Coral bleaching: causes and consequences. In: Lessios HA, MacIntyre IG (eds) Proceedings of the 8th International Coral Reef Symposium. Smithsonian Tropical Research Institute, Panamá, p 65-74

Brown BH, Howard LS (1985) Assessing the effects of 'stress' on reef corals. Adv Mar Biol 22:1-63

Cameron AM, Endean R, deVantier LM (1991) The effect of Acanthaster planci predation on populations of two species of massive corals. Hydrobiologia 216/217:257-262

Chornesky EA (1989) Repeated reversals during spatial competition between corals. Ecology 70:843-855

Fine M, Zibrowius H, Loya Y (2001) Oculina patagonica: a non lessepsian scleractinian coral invading the Mediterranean Sea. Mar Biol 138:1195-1203

Gladfelter EH (1982) White-band disease in Acropora palmata: implications for the structure and growth of shallow reefs. Bull Mar Sci 32:639-643

Gleason DF, Wellington GM (1993) Ultraviolet-radiation and coral bleaching. Nature 365:836-838

Glynn PW (1991) Coral-reef bleaching in the 1980s and possible connections with global warming. Trends Ecol Evol 6:175-179

Glynn PW (1993) Coral-reef bleaching - ecological perspectives. Coral Reefs 12:1-17

Goreau TJ, Macfarlane AH (1990) Reduced growth rate of Montastrea annularis following the 1987-1988 coral bleaching event. Coral Reefs 8:211-215

Harrison PL, Wallace CC (1990) Reproduction, dispersal and recruitment of scleractinian corals. In: Dubinski Z (ed) Coral reefs, ecosystems of the world, Vol 25. Elsevier, Amsterdam, p 133-206

Hoegh-Guldberg O (1999) Climate change coral bleaching and the world's coral reefs. Mar Freshw Res 50:839-866

Jokiel PL (1980) Solar ultraviolet radiation and coral reef epifauna. Science 207:1069-1071

Jokiel PL, Coles SL (1990) Response of Hawaiian and other Indo-Pacific reef corals to elevated temperature. Coral Reefs 8:155-162

Kozlowski J, Wiegert RG (1986) Optimal allocation of energy to growth and reproduction. Theor Popul Biol 29:16-37

Kramarsky-Winter E, Loya Y (2000) Tissue regeneration in the coral Fungia granulosa: the effect of extrinsic and intrinsic factors. Mar Biol 137:867-873

Kushmaro A, Loya Y, Fine M, Rosenberg E (1996) Bacterial infection and bleaching. Nature 380:396

Kushmaro A, Rosenberg E, Fine M, Loya Y (1998) Effect of temperature on bleaching of the coral Oculina patagonica by Vibrio AK-1. Mar Ecol Prog Ser 171:131-137

Lesser MP, Stochaj WR, Tapley DW, Shick JM (1990) bleaching in coral-reef anthozoans - effects of irradiance, ultraviolet radiation, and temperature on the activities of protective enzymes against active oxygen. Coral Reefs 8: $225-232$

Loya Y (1972) Community structure and species diversity of hermatypic corals at Eilat, Red Sea. Mar Biol 13:100-123

Loya Y (1976a) Effects of water turbidity and sedimentation on community structure of Puerto Rican corals. Bull Mar Sci 26:450-466

Loya Y (1976b) Recolonization of Red Sea corals affected by natural catastrophes and man-made perturbations. Ecology 57:278-289 
Meesters EH, Bak RPM (1993) Effects of coral bleaching on tissue regeneration potential and colony survival. Mar Ecol Prog Ser 96:189-198

Meesters EH, Pauchli W, Bak RPM (1997) Predicting regeneration of physical damage on a reef building coral by regeneration capacity and lesion shape. Mar Ecol Prog Ser 146:91-99

Muscatine L, Porter JW (1977) Reef corals: naturalistic symbiosis adapted to nutrient poor environments. BioScience 27:454-460

Muscatine L, McCloskey LR, Marian RF (1981) Estimating the daily contribution of carbon from zooxanthellae to coral animal respiration. Limnol Oceanogr 26:601-611

Oren U, Rinkevich B, Loya Y (1997) Oriented intra-colonial transport of ${ }^{14} \mathrm{C}$ labelled materials during regeneration in scleractinian corals. Mar Ecol Prog Ser 161:117-121

Oren U, Brickner I, Loya Y (1998) Prudent sessile feeding by the corallivore snail Coralliophila violacea on coral energy sinks. Proc R Soc Lond Ser B Biol Sci 265:2043-2050

Oren U, Benayahu Y, Lubinevsky H, Loya Y (2001) Extent of coral colony integration during regeneration. Ecology 82: 802-813

Pearse VB, Muscatine L (1971) Role of symbiotic algae (zooxanthellae) in coral calcification. Biol Bull 141:350-363

Peters EC (1984) A survey of cellular reactions to environmental stress and disease in Caribbean scleractinian corals. Helgol Meeresunters 37:113-137

Rogers CS (1990) Responses of coral reef and reef organisms to sedimentation. Mar Ecol Prog Ser 62:185-202

Rogers CS (1993) Hurricanes and coral reefs: the intermediate disturbance hypothesis revisited. Coral Reefs 12: $127-137$

Scoffin TP (1993) The geological effects of hurricanes on coral reefs and the interpretation of storm deposits. Coral Reefs 12:203-221

Editorial responsibility: Otto Kinne (Editor),

Oldendorf/Luhe, Germany
Szmant A, Gassman NJ (1990) The effect of prolonged 'bleaching' on the tissue biomass and reproduction of the reef coral Montastrea annularis. Coral Reefs 8:217-224

Taylor DL (1977) Intra-colonial transport of organic compounds and calcium in some Atlantic reef corals. In: Taylor DL (ed) Proceedings of the 3rd International Coral Reef Symposium. Rosenstiel School of Marine and Atmospheric Science, University Miami, Miami, p 431-436

Vreeland HV, Lasker HR (1989) Selective feeding of the polychaete Hermodice carunculata Pallas on Caribbean gorgonians. J Exp Mar Biol Ecol 129:265-277

Wahle CM (1983) Regeneration of injuries among Jamaican gorgonians: the role of colony physiology and environment. Biol Bull 165:778-790

Ward S (1995) The effect of damage on the growth, reproduction and storage of lipids in the scleractinian coral Pocillopora damicornis (Linnaeus). J Exp Mar Biol Ecol 187: 193-206

Ward S (2000) Changes in coral reproduction following slight changes in temperature and bleaching. In: Okamoto $M$ (ed) Proc JAMSTEC Int Coral reef Symp, Coral reef biodiversity and health as indicators of invironmental change. February 2000, Tokyo, Japan, 94-111. Science and Technology Agency

Wilkinson CR (1999) The 1997-1998 mass bleaching event around the world. Compilation of Internet reports, global reef monitoring network. Australian Institute of Marine Science, Townsville

Wilkinson CR (2000). The 1997-98 mass coral bleaching and mortality event: 2 years on. In: Wilkinson CR (ed) Status of coral reefs of the world: 2000. Australian Institute of Marine Science, Townsville, p 21-35

Witman JD (1988) Effects of predation by the fireworm Hermodice carunculata on milleporid hydrocorals. Bull Mar Sci 42:446-458

Submitted: July 19, 2001; Accepted: November 8, 2001 Proofs received from author(s): May 8, 2002 